\title{
Construction and application of a human scFv phage display library based on Cre-LoxP recombination for anti-PCSK9 antibody selection
}

\author{
YUAN DONG $^{1 *}$, FANWEI MENG ${ }^{1 *}$, ZHIHENG WANG ${ }^{2,3}$, TIANYI YU $^{1}, \mathrm{AN} \mathrm{CHEN}^{3}, \mathrm{SONG} \mathrm{XU}^{4}$, \\ JIANMING WANG ${ }^{4}$, MOLI YIN $^{1}$, LU TANG $^{1}$, CHUANMIN HU $^{4}$, HUIYAN WANG $^{1}$ and JIANHUI CAI ${ }^{1}$ \\ ${ }^{1}$ Jilin Collaborative Innovation Center for Antibody Engineering, Jilin Medical University, Jilin, Jilin 132013; \\ ${ }^{2}$ Clinical Laboratory, 944th Hospital of People's Liberation Army, Jiuquan, Gansu 735000; \\ ${ }^{3}$ Department of Clinical Biochemistry, Faculty of Pharmacy and Laboratory Medicine, Army Medical University, \\ Chongqing 400038; ${ }^{4}$ Research and Development Department, Chongqing Biomean Technology Co., Ltd., \\ Chongqing 400715, P.R. China
}

Received May 9, 2020; Accepted November 10, 2020

DOI: $10.3892 /$ ijmm.2020.4822

\begin{abstract}
A large human natural single-chain fragment variable ( $\mathrm{scFv}$ ) phage library was constructed based on Cre-LoxP recombination, and used to successfully identify antibodies against proprotein convertase subtilisin/kexin type 9 (PCSK9). The library was derived from 400 blood samples, 30 bone marrow samples, and 10 cord blood samples from healthy donors. Lymphocytes were isolated from each sample and cDNA was synthesized using reverse transcription-quantitative PCR. Two-step overlap PCR was then used for $\mathrm{scFv}$ synthesis using a LoxP peptide as the linker. The $s c F v$ gene was inserted into the phagemid vector $\mathrm{pDF}$ by enzymatic digestion and ligation, and then transformed into Escherichia coli (E. coli) SS320 to establish a primary antibody library in the form of scFvs. A primary antibody library consisting of $5 \times 10^{7}$ peripheral blood and umbilical cord blood sources, as well as a primary antibody library of $5 \times 10^{7}$ bone marrow samples were obtained. By optimizing the recombination conditions, the primary phage library was used to infect $E$. coli BS1365 strain (which expresses the Cre enzyme), and a human scFv recombinant library with a size of $1 \times 10^{11}$ was obtained through Cre-LoxP enzyme-mediated heavy and light chain replacement and recombination. This
\end{abstract}

Correspondence to: Professor Jianhui Cai or Professor Huiyan Wang, Jilin Collaborative Innovation Center for Antibody Engineering, Jilin Medical University, 5 Jilin Avenue, Jilin, Jilin 132013, P.R. China

E-mail: 13844208760@163.com

E-mail: zswhy518@163.com

*Contributed equally

Key words: proprotein convertase subtilisin-like/kexin type 9, low-density lipoprotein, receptor, fully human single-chain fragment variable phage display antibody library, Cre-LoxP, hypercholesterolemia constructed recombinant library was employed to screen for antibodies against recombinant PCSK9. After four rounds of selection, a fully human antibody (3D2) was identified with a binding affinity of $1.96 \pm 1.56 \times 10^{-10} \mathrm{M}$ towards PCSK9. In vitro, the PCSK9/low-density lipoprotein receptor (LDLR) pathway of Hep-G2 cells was inhibited by 3D2 treatment, thereby increasing LDL uptake in these cells. In addition, combination treatment with 3D2 and statin was more effective at increasing LDLR levels than treatment with 3D2 or statin alone. Furthermore, 3D2 resulted in a 3-fold increase in hepatic LDLR levels, and lowered total serum cholesterol by up to $61.5 \%$ in vivo. Taken together, these results suggest that the constructed human Cre-LoxP scFv phage display library can be used to screen fully human scFv, and that 3D2 may serve as a candidate hypolipidemic therapy.

\section{Introduction}

For several decades, phage display technology has been widely used for the selection of fully human antibodies. At present, the most advanced phage antibody library is the Cre-LoxP recombinant antibody library, which was constructed based on the single vector pDF (1). The Cre-LoxP system mediates site-specific DNA recombination, and is thereby the core to gene-targeting technology. Furthermore, the phagemid vector pDF contains two non-homologous LoxP sites on both ends of the antibody gene, which can be recognized by Cre recombinant enzyme. With the application of Cre-LoxP recombination in the construction of a phage display antibody library, different heavy (VH) and light (VL) chain variable regions can be freely recombined, allowing for the indefinite repetition of gene recombination, so as to realize the construction of antibody libraries with large repertoire size and diversity (2).

Proprotein convertase subtilisin/kexin9(PCSK9), a member of the subtilisin-like proprotein convertase family, serves a role in low-density lipoprotein receptor (LDLR)-lysosome pathways, as well as cholesterol and fatty acid metabolism $(3,4)$. Cohen et al $(5)$ reported that genetical alterations 
in the PCSK9 gene, such as gain-of-function mutations, could elevate serum LDL-C levels ( $>300 \mathrm{mg} / \mathrm{dl})$, and by contrast, that loss-of-function mutations may lower serum LDL-C $(<100 \mathrm{mg} / \mathrm{dl})$, resulting in cardiovascular disease (6). Various approaches to inhibiting PCSK9 have been reported for hypercholesterolemia treatment, including the use of antisense oligonucleotides, lipidoid nanoparticle formulated short interfering RNAs directed against PCSK9 mRNA $(7,8)$, antibodies and LDLR subfragments (9).

Monoclonal antibodies are the primary type of commercial PCSK9 inhibitors. As a first generation antibody, the murine monoclonal antibody possesses desirable immunogenicity (10), though fully-humanized monoclonal antibodies exhibit superior properties, overcoming the shortcomings of murine monoclonal and chimeric monoclonal antibodies. As such, fully-humanized antibodies have become integral to the development of antibody-based therapeutics (11).

In the present study, three $5 \times 10^{7}$ primary antibody libraries were constructed using 400 blood samples, 30 bone marrow samples and 10 cord blood samples, respectively, all from healthy donors. By optimizing the recombination conditions, a fully human recombinant single-chain fragment variable ( $\mathrm{scFv}$ ) phage library (size, $1 \times 10^{11}$ ) was obtained. Sequencing 60 random scFvs showed that the diversity of antibody genes in the library was consistent with the antibody gene distribution of the human embryo line. The PCSK9 antigen was used to screen the fully human scFv library, and five different $\mathrm{scFv}$ sequences were obtained that specifically targeted to PCSK9. After constructing the expression vectors of five selected scFvs, transient expression revealed that antibody expression levels ranged from 50-200 mg/l; 3D2 was found to have a coordination effect when used with statins, which promoted the absorption of LDLR and LDL in hepatic Hep-G2 cells. Animal experiments showed that 3D2 increased the expression of LDLR and significantly reduced total serum cholesterol. Therefore, the results of the present study indicate that the constructed large fully human $\mathrm{scFv}$ phage display library can be used to screen for therapeutic antibodies, and that 3D2 has great potential for use as a candidate PCSK9 inhibitor.

\section{Materials and methods}

Construction of a fully human scFv phage display antibody library

RNA extraction. The blood of 400 healthy donors, the bone marrow of 30 healthy donors and cord blood samples from 10 healthy donors were kindly provided by the Affiliated Hospital of Jilin Medical University (Jilin, China) between January 2016 and June 2016. The study was approved by the ethics committee of Jilin Medical University (2016-LW012) prior to the start of the study. All donors were healthy volunteers aged 18-60, and of both sexes. The lymphocytes from these samples were isolated using a human blood lymphocyte isolation kit (cat. no. P8610; Solarbio Science and Technology Co., Ltd.) Total RNA was extracted from the lymphocytes using TRIzol ${ }^{\circledR}$ reagent (SinoGene Scientific Co., Ltd.), and the RNA samples were analysed by $1 \%$ agarose gel electrophoresis.

$c D N A$ synthesis. First chain cDNA was synthesized with a reverse transcription kit (Shanghai Hifun Biotechnology Co.,
Ltd.) according to the manufacturer's instructions, using total RNA as the template.

PCR amplification of scFvs. Stepwise PCR (Fig. 1) was used to synthesize the scFvs for library construction, using a total of 22 different and degenerate primers as described in Table I. Firstly, VH and VL $\left(\mathrm{V} \kappa_{\kappa} / \mathrm{V} \lambda\right)$ chain variable regions were amplified using cDNA as the template. The PCR reactions (50 $\mu \mathrm{l}$ each) contained $2 \mu \mathrm{l} \mathrm{cDNA} \mathrm{(40} \mathrm{ng/} \mu \mathrm{l}), 1 \mu \mathrm{l}$ forward primer $(10 \mu \mathrm{M}), 1 \mu \mathrm{l}$ reverse primer $(10 \mu \mathrm{M}), 0.5 \mu \mathrm{l}$ Q5 DNA

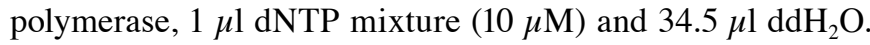
The PCR thermocycling conditions were as follows: 1 Cycle at $95^{\circ} \mathrm{C}$ for $3 \mathrm{~min} ; 30$ cycles at $95^{\circ} \mathrm{C}$ for $30 \mathrm{sec}, 57^{\circ} \mathrm{C}$ for $30 \mathrm{sec}$ and $72^{\circ} \mathrm{C}$ for $45 \mathrm{sec}$; and a final incubation at $72^{\circ} \mathrm{C}$ for $5 \mathrm{~min}$. Then, the PCR products (ranging around $400 \mathrm{bp}$ ) were recovered and further amplified separately for VH- and VL-linkers with a BssHII/NheI recognition site and LoxP511 sequence. Finally, the VH- and VL-linkers were joined by overlap PCR. The PCR program comprised two steps: 1 Cycle at $95^{\circ} \mathrm{C}$ for $3 \mathrm{~min}$; and 2 cycles at $95^{\circ} \mathrm{C}$ for $1 \mathrm{~min}, 60^{\circ} \mathrm{C}$ for $30 \mathrm{sec}, 55^{\circ} \mathrm{C}$ for $50 \mathrm{sec}$ and $72^{\circ} \mathrm{C}$ for $1 \mathrm{~min}$. Then the HVKEXfor/PVHback primers were added according to previous reports (1). The subsequent PCR conditions were as follows: 5 Cycles of $95^{\circ} \mathrm{C}$ for $1 \mathrm{~min}, 60^{\circ} \mathrm{C}$ for $30 \mathrm{sec}, 55^{\circ} \mathrm{C}$ for $50 \mathrm{sec}$ and $72^{\circ} \mathrm{C}$ for $1 \mathrm{~min}$; and 23 cycles at $95^{\circ} \mathrm{C}$ for $1 \mathrm{~min}, 60^{\circ} \mathrm{C}$ for $45 \mathrm{sec}$, and $72^{\circ} \mathrm{C}$ for $1 \mathrm{~min}$. The amplicons (ranging around $800 \mathrm{bp}$ ) were recovered and stored at $-80^{\circ} \mathrm{C}$.

Preparation of M13KO7-infected electrocompetent E. Coli $S S 320$ cells. According to previously described methods (12), $500 \mu \mathrm{l}$ of $E$. Coli SS320 $\left(\mathrm{Tet}^{+}\right)$at exponential phase $\left(\mathrm{OD}_{600}=0.8\right)$ was mixed with $6 \times 10^{8} \mathrm{pfu} / \mathrm{ml}$ of M13K07 helper phage $\left(\mathrm{Kana}^{+}\right)$and $4 \mathrm{ml}$ of 2YT top agar. The mixture was poured onto LB agar plate (supplemented with $5 \mu \mathrm{g} / \mathrm{ml}$ tetracycline) and incubated for $20 \mathrm{~h}$ at $37^{\circ} \mathrm{C}$. A single plaque was selected and inoculated into $1 \mathrm{ml}$ of $2 \mathrm{YT} / \mathrm{kana} / \mathrm{tet}$ medium $(10 \mathrm{~g} / \mathrm{l}$ yeast extract, $16 \mathrm{~g} / \mathrm{l}$ tryptone, $5 \mathrm{~g} / 1 \mathrm{NaCl}, 15 \mathrm{~g} / 1$ granulated agar, $25 \mu \mathrm{g} / \mathrm{ml}$ kanamycin and $5 \mu \mathrm{g} / \mathrm{ml}$ tetracycline; $\mathrm{pH}$ to 7.0$)$ and incubated for $8 \mathrm{~h}$ at $37^{\circ} \mathrm{C}$. The culture was then transferred to $250 \mathrm{ml}$ of $2 \mathrm{YT} / \mathrm{kana}$ medium and incubated with shaking at $200 \mathrm{x} \mathrm{g}$ at $37^{\circ} \mathrm{C}$ overnight. $5 \mathrm{ml}$ of the overnight culture was inoculated into $900 \mathrm{ml}$ of superbroth/tet/kana medium (12 g/l tryptone, $24 \mathrm{~g} / 1$ yeast extract, $5 \mathrm{ml} / 1$ glycerol, $0.17 \mathrm{M}$ $\mathrm{KH}_{2} \mathrm{PO}_{4}, 0.72 \mathrm{M} \mathrm{K}_{2} \mathrm{HPO}_{4}, 5 \mu \mathrm{g} / \mathrm{ml}$ tetracycline and $25 \mu \mathrm{g} / \mathrm{ml}$ kanamycin) and incubated with shaking at $200 \mathrm{x}$ g at $37^{\circ} \mathrm{C}$ until the absorbance had reached $0.8\left(\mathrm{OD}_{600}\right)$. The culture was centrifuged at $5,000 \mathrm{x}$ g for $15 \mathrm{~min}$ at $4^{\circ} \mathrm{C}$. The supernatant was discarded and the pellet was washed with cold $1 \mathrm{mM}$ HEPES (pH 7.5) 3 times. By centrifuging at 5,000 x g for $15 \mathrm{~min}$ at $4^{\circ} \mathrm{C}$, the precipitate was first resuspended with $20 \mathrm{ml}$ of $1 \mathrm{mM}$ HEPES containing $10 \%$ (v/v) glycerol and finally resuspended with $1 \mathrm{ml}$ of $10 \%(\mathrm{v} / \mathrm{v})$ cold glycerol. Then the cells were snap frozen with liquid nitrogen and stored at $-80^{\circ} \mathrm{C}$.

Transformation and library construction. According to previously described methods (12), the scFv fragments $(1 \mu \mathrm{g})$ were digested using BssHII and NheI (1 $\mu \mathrm{g}$ each) and inserted into a pDF vector (also digested with $B s s \mathrm{HII}$ and NheI) (Fig. 4; $\mathrm{Amp}^{+}, 1.78 \mu \mathrm{g}$ ) using T4 ligase at $16^{\circ} \mathrm{C}$. The constructs were purified using the QIAquick PCR purification kit (cat. no. 28104; Qiagen, Dusseldorf) and electroporated into $25 \mu \mathrm{l}$ M13KO7-infected SS320 electrocompetent cells at 2,500 V, $200 \Omega, 25 \mu \mathrm{F}$ and $4 \mathrm{msec}$. Then, $25 \mathrm{ml} \mathrm{SOC} \mathrm{media}$ 
Table I. Primers used for gene amplification.

Forward primers for $\mathrm{VH}$

$\begin{array}{ll}\text { PVHfor1 } & \text { TAT CCT CGA GCG GTA CCS AGG TSC AGC TGG TRC AGT CTG G } \\ \text { PVHfor2 } & \text { TAT CCT CGA GCG GTA CCS AGG TGC AGC TGK TGG AG } \\ \text { PVHfor3 } & \text { TAT CCT CGA GCG GTA CCC AGR TCA CCT TGA AGG AGT CT } \\ \text { PVHfor4 } & \text { TAT CCT CGA GCG GTA CCC AGS TGC AGCT RCA GSA GT }\end{array}$

Reverse primer for $\mathrm{VH}$

PVHback

GGC GGA TGC GCT AGC TGA RGA GAC RGT GAC C

Forward primers for $\mathrm{V} \kappa$

$\begin{array}{ll}\text { HVK1 } & \text { TAAT GCGCGC ATG CCG MCA TCC RGW TGA CCC AGT CTC C } \\ \text { HVK2 } & \text { TAAT GCGCGC ATG CCG ATA TTG TGA TGA CYC AGW CTC C } \\ \text { HVK3 } & \text { TAAT GCGCGC ATG CCG AAA TTG TGW TGA CRC AGT CTC C } \\ \text { HVK4 } & \text { TAAT GCGCGC ATG CCG AAA CGA CAC TCA CGC AGT CT }\end{array}$

Reverse primers for $\mathrm{V} \kappa$

PVK1back

GGT CGA CCC TCC GGA ACG TTT GAT HTC CAS CTT GGT

PVK2back

GGT CGA CCC TCC GGA ACG TTT AAT CTC CAG TGC TGT

Forward primers for $\mathrm{V} \lambda$
HVL1
HVL2
TAAT GCGCGC ATG CCC AGT CTG TGY TGA CKC AGC C
HVL3
TAAT GCGCGC ATG CCC AGT CTG CCC TGA CTC AGC C
HVL4
TAAT GCGCGC ATG CCT CCT MTG AGC TGA CWC AG
HVL5
TAAT GCGCGC ATG CCC AGT YTG TGC TGA CTC AAT C
HVL6
TAAT GCGCGC ATG CCC AGR CTG TGG TGA CYC AGG AG
HVL7
TAAT GCGCGC ATG CCA ATT TTA TGC TGA CTC AG
TAAT GCGCGC ATG CCC AGK MTG RGC TGA YGC AGC CAC CCT C

Reverse primers for $\mathrm{V} \lambda$

PVLback

GGT CGA CCC TCC GGA ACC TAG GAC GGT SAG CTT GGT CCC

Extended reverse primer for $\mathrm{VH}$,

used for overlap PCR

PVHL

CCA TAA CTT CGT ATA ATG TAT ACT ATA CGAAGT TAT CCT CGA GCG GTA CC

Extended forward primers

for $\mathrm{V} \kappa$ and $\mathrm{V} \lambda$

HVKEXfor

GAG GAG GAG ATA ATG CGC GCA TGC C

Extended reverse primers for VL,

used for overlap PCR

PVLEX

GGA TAA CTT CGT ATA GTA TAC ATT ATA CGA AGT TAT GGT CGA CCC TCC GGA $\overline{A C}$

Sequences with single underline were recognition sites (BssHII recognition site GCGCGC; NheI recognition site GCTAGC); sequences with double underline were overlap sequence (LoxP511 gene). The degenerate codons were bolded, where $\mathrm{R}=$ purine $(\mathrm{A}$ or $\mathrm{G})$, $\mathrm{Y}=\mathrm{pyrimidine}$ ( $\mathrm{C}$ or $\mathrm{T}$ ), $\mathrm{M}=\mathrm{A}$ or $\mathrm{C}, \mathrm{K}=\mathrm{G}$ or $\mathrm{T}, \mathrm{S}=\mathrm{G}$ or $\mathrm{C}, \mathrm{H}=\mathrm{A}, \mathrm{T}$ or $\mathrm{C}$ and $\mathrm{W}=\mathrm{A}$ or $\mathrm{T}$. 


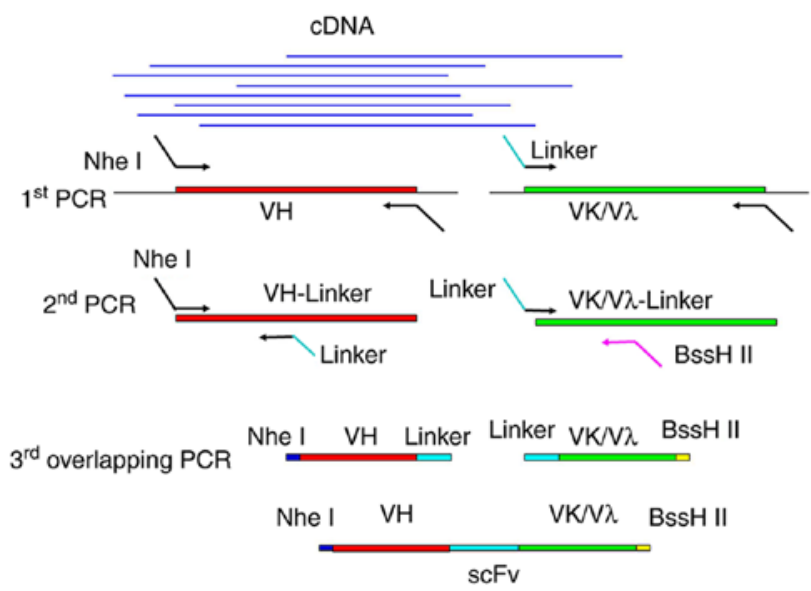

Figure 1. Diagram of stepwise PCR amplification design. RNA was extracted from lymphocytes acquired from different human samples, and reverse transcribed into cDNA, which was used as the template for stepwise PCR. Firstly, $\mathrm{VH}$ and $\mathrm{VL}(\mathrm{V} \kappa / \mathrm{V} \lambda)$ were amplified using the cDNA template. PCR products ranging around $400 \mathrm{bp}$ were recovered and further separately amplified for VH- and VL-linkers with a Bss HII/NheI recognition site and LoxP511 sequence. Finally, the VH- and VL-linkers were joined by overlap PCR of scFvs. $\mathrm{VH}$, heavy chain variable region; $\mathrm{VL}$, light chain variable region; $\mathrm{scFv}$, single-chain fragment variable.

was added ( $5 \mathrm{~g} / 1$ bacto-yeast extract, $20 \mathrm{~g} / 1$ bacto-tryptone, $0.5 \mathrm{~g} / 1 \mathrm{NaCl}, 0.2 \mathrm{~g} / 1 \mathrm{KCl}, 0.01 \mathrm{M} \mathrm{MgCl}_{2}$ and $0.02 \mathrm{M}$ glucose; $\mathrm{pH} 7.0)$ and the cultures were incubated at $37^{\circ} \mathrm{C}$ for $40 \mathrm{~min}$ with agitation $(200 \mathrm{x} \mathrm{g})$. Subsequently, $10 \mu \mathrm{l}$ of the culture was diluted $\left(1: 10^{8}\right)$ and plated onto 2YT/Amp agar medium (2YT supplemented with $50 \mu \mathrm{g} / \mathrm{ml}$ ampicillin) for overnight incubation at $37^{\circ} \mathrm{C}$, which was used to evaluate and calculate the size of the $\mathrm{scFv}$ phage display library. The rest of the culture was inoculated into $112 \mathrm{YT} / \mathrm{Amp} / \mathrm{kan} / \mathrm{IPTG}$ media (supplemented with $50 \mu \mathrm{g} / \mathrm{ml}$ ampicillin, $25 \mu \mathrm{g} / \mathrm{ml}$ kanamycin and $25 \mathrm{mM}$ IPTG) and incubated overnight at $37^{\circ} \mathrm{C}$ with gentle shaking. The culture was then centrifuged at $10,000 \mathrm{x} \mathrm{g}$ for $15 \mathrm{~min}$ at $4^{\circ} \mathrm{C}$. The supernatant was removed, mixed with $20 \%$ PEG $8000-2.5 \mathrm{M} \mathrm{NaCl}$ solution, and left to stand on ice for $20 \mathrm{~min}$. After centrifuging at $10,000 \mathrm{x}$ for $20 \mathrm{~min}$ at $4^{\circ} \mathrm{C}$, the phage precipitate was resuspended with $20 \mathrm{ml} 1 \mathrm{X}$ PBS to generate the primary library. The recombinant phage antibody library was constructed by infecting the mid-log-phage-BS1365 strain $\left(\mathrm{Cre}^{+}, \mathrm{OD}_{600} 0.8\right)$ with $250 \mu \mathrm{l}$ of the primary library $\left(1 \times 10^{12} \mathrm{pfu} / \mathrm{ml}\right)$ at a multiplicity of infection (MOI) of 200:1. After standing at $37^{\circ} \mathrm{C}$ for $1 \mathrm{~h}, 400 \mathrm{ml} 2 \mathrm{YT} / \mathrm{Amp}$ media was added and the culture was incubated at $37^{\circ} \mathrm{C}(200 \mathrm{x} \mathrm{g})$ until the absorbance had reached $0.5\left(\mathrm{OD}_{600}\right)$. Then, $5 \mathrm{ml}$ helper phage (M13KO7; 5x10 ${ }^{10} \mathrm{pfu} / \mathrm{ml}$ ) was added at a ratio of 3000:1, and the culture was gently shaken. After standing at $37^{\circ} \mathrm{C}$ for $1 \mathrm{~h}$, the phage library was collected and used to infect 1 liter of the mid-log-phase-OMNImax 2 strain $\left(\mathrm{Tet}^{+}, \mathrm{OD}_{600} 0.8\right)$ at an $\mathrm{MOI} \leq 1 ; 10 \mathrm{ml}$ of M13KO7 $\left(5 \times 10^{10} \mathrm{pfu} / \mathrm{ml}\right)$ was then added and shaken at $30^{\circ} \mathrm{C}$ for $1 \mathrm{~h}$. The resulting recombinant human scFv phage library was stored in glycerol at $-80^{\circ} \mathrm{C}$. The library size was calculated as follows: Library size (cells $/ \mathrm{ml})=$ number of colonies $\times 10^{3} \mathrm{x}$ dilution ratio.

Human recombinant PCSK9 protein preparation. Human PCSK9 (Genbank AX207686) was amplified from Hep-G2 cells by reverse transcription PCR, and its sequence was confirmed by sequencing. The Hep-G2 cells (Shanghai Biowing Applied Biotechnology Co., Ltd.) were authenticated as a hepatocellular carcinoma cell line using short tandem repeat profiling, which was also conducted by Shanghai Biowing Applied Biotechnology Co., Ltd. The cells were maintained in RPMI-1640 (Gibco) supplemented with $10 \%(\mathrm{v} / \mathrm{v})$ fetal bovine serum (FBS, Gibco) and antibiotics (100 IU/ml penicillin and $100 \mathrm{mg} / \mathrm{ml}$ streptomycin) at $37^{\circ} \mathrm{C}$ and $5 \% \mathrm{CO}_{2}$. Then, the gene was cloned into the pcDNA3.1-hIgG1FC vector along with a $6 \mathrm{X}$ His tag, between the HindIII and XhoI sites The recombinant plasmid (30 $\mu \mathrm{g})$ was then used to transfect $5 \times 10^{7}$ CHO-K1 cells using Lipofectamine ${ }^{\circledR} 6000$ transfection reagent (cat. no. C0528; Beyotime Biotechnology Co., Ltd.). Recombinant PCSK9 protein was purified from the cell supernatant using PrepEase ${ }^{\circledR}$ His-tag protein purification resin (Biomart Co., Ltd.). The CHO-K1 cells were obtained from the American Type Culture Collection (ATCC ${ }^{\circledR}$ CCL-61 ${ }^{\mathrm{TM}}$ ) and maintained in RPMI-1640 (Gibco) supplemented with 10\% (v/v) FBS (Gibco) and antibiotics (100 IU/ml penicillin and $100 \mathrm{mg} / \mathrm{ml}$ streptomycin) at $37^{\circ} \mathrm{C}$ and $5 \% \mathrm{CO}_{2}$.

Selection of antibodies against human PCSK9. The recombinant human $\mathrm{scFv}$ phage library was screened against PCSK9 as previously reported $(13,14)$. Immunotubes were coated with detection antigen (purified PCSK9) diluted to $100 \mu \mathrm{g} / \mathrm{ml}$ ( $2 \mathrm{ml} /$ immunotube) and incubated at $4^{\circ} \mathrm{C}$ overnight. After washing 3 times with PBS, the immunotubes were blocked with $2 \%(\mathrm{w} / \mathrm{v}) \mathrm{BSA}$ in PBS. The diluted recombinant phage particles $\left(10^{11} \mathrm{pfu} / \mathrm{ml}\right)$ were subsequently added into the coated immunotubes and incubated at $37^{\circ} \mathrm{C}$ for $2 \mathrm{~h}$. The immunotubes were then washed 10 times with PBST (PBS containing $0.1 \%$ Tween-20) and 10 times with PBS only, to remove unbound phage. Bound phage was eluted with $100 \mathrm{mM}$ triethylamine (Sigma-Aldrich; Merck KGaA) and neutralized with $500 \mu \mathrm{l}$ of $1 \mathrm{M}$ Tris-HCl (pH 7.5). Mid-log phase E. coli TG1 cells were infected with the eluted phage, plated onto several 2YT-agar plates and cultured until individual colonies had formed. Each clone was used to transform mid-log phase E. coli TG1 cells (using M13KO7 phages), which were screened using a competitive phage-ELISA. The screening process was repeated for 4 rounds.

Expression and purification of antibodies against PCSK9. The selected human PCSK9 scFvs in the phages were amplified by PCR and inserted into a modified mammalian expression vector (pFUSE2-CLIg-hk and pFUSE-CHIg-hG1; InvivoGen). The plasmids were used to transfect 293 cells using the ExpiFectamine ${ }^{\mathrm{TM}} 293$ Transfection Kit (Gibco; Thermo Fisher Scientific, Inc.), and the culture supernatant was collected after 8 days. The antibodies were separated and purified from the supernatant using a Protein A Sepharose column (GE Healthcare Bio-Sciences). The integrity of the antibodies was determined by ELISA and SDS-PAGE.

Biolayer interferometry (BLI) analysis. The affinity measurements were analysed by BLI technology using a Pall ForteBio's BLI-based Octet RED96e system (ForteBio; Sartorius AG) combined with Octet version 13.1.0 software, according to the manufacturer's recommendation. The purified anti-PCSK9 
antibodies were biotinylated using the Biotin Labelling Kit- $\mathrm{NH}_{2}$ (Dojindo Molecular Technologies, Inc.). Briefly, $1 \mathrm{mg}$ anti-PCSK9 antibody was mixed in a filtration tube with $100 \mu 1 \mathrm{NH} 2$-reactive biotin $(10 \mathrm{mM})$, and incubated at $37^{\circ} \mathrm{C}$ for $10 \mathrm{~min}$. The tube was then centrifuged at $6,000 \mathrm{xg}$ for $30 \mathrm{~min}$ at $4^{\circ} \mathrm{C}$ to remove uncombined biotin reagent. The biosensors in the Pall ForteBio's BLI-based Octet ${ }^{\circledR}$ RED96e system were hydrated as follows: $200 \mu \mathrm{l} 1 \mathrm{X}$ Kinetics Buffer was added to a each well of a round-bottom microplate (the hydration plate), which was placed into the biosensor tray of the system. The biosensors were dipped into the wells for $10 \mathrm{~min} ; 200 \mu 150$, $25,5,2.5$ or $0.5 \mu \mathrm{g} / \mathrm{ml}$ biotinylated anti-PCSK9 antibody was added to the wells of a black 96-well polypropylene microplate (the sample plate), followed by $200 \mu 1$ PCSK 9 antigen ( $200 \mathrm{nM}$ ). Then, $200 \mu$ l biotinylated anti-PCSK 9 antibody $(50 \mu \mathrm{g} / \mathrm{ml})$ was added to the wells, and biotinylated anti-PCSK9 antibody without PCSK9 antigen served as the negative control. The plate temperature was set to $30^{\circ} \mathrm{C}$ in the Octet ${ }^{\circledR}$ software, the sample plate was placed on the sample plate stage inside the Octet $^{\circledR}$ system, and the biosensor hydration assembly was placed on the biosensor stage. The settings for the affinity assay were as follows: Equilibration for $60 \mathrm{sec}$, loading for $400 \mathrm{sec}$, baseline for $600 \mathrm{sec}$, association for $400 \mathrm{sec}$ and dissociation for 3,600 sec at a flow rate of $1,000 \mathrm{xg}$. After the assay, the shapes of the individual binding curves were observed and the binding association $\left(\mathrm{K}_{\mathrm{on}}\right)$ and dissociation rate constants $\left(\mathrm{K}_{\mathrm{off}}\right)$ are calculated from a global fitting analysis assuming a 1:1 binding model using the Octet Data Analysis software. The affinity constant $\left(\mathrm{K}_{\mathrm{D}}\right)$ was determined from the ratio of the rate constants: $\mathrm{K}_{\mathrm{D}}=\mathrm{K}_{\text {off }} / \mathrm{K}_{\text {on }}$.

Western blot analysis. Hep-G2 cells or liver tissues were lysed to determine the expression levels of LDLR. Cells were treated with radio-immunoprecipitation assay buffer and protease inhibitor cocktail (both from Millipore Sigma) and incubated for $30 \mathrm{~min}$ to stop proteolysis. The lysate was centrifuged at $12,000 \mathrm{xg}$ for $30 \mathrm{~min}\left(4^{\circ} \mathrm{C}\right)$, and $60 \mu \mathrm{g}$ total protein was electrophoresed on a $10 \%$ polyacrylamide gel; the proteins were transferred to a PVDF membrane for $2 \mathrm{~h}$ at $300 \mathrm{mV}$, and then washed 5 times with TBST [ $50 \mathrm{mM}$ Tris-Cl (pH 7.5), $100 \mathrm{mM} \mathrm{NaCl}$ and $0.5 \%$ Tween-20]. The membranes were blocked with $5 \% \mathrm{BSA}$ for $2 \mathrm{~h}$ at $37^{\circ} \mathrm{C}$, and then incubated with diluted primary antibodies $(0.25 \mu \mathrm{g} / \mathrm{ml}$ goat anti-mouse LDLR, rabbit anti-human LDLR or mouse anti-GAPDH antibodies) (Abcam, Cambridge) at $4^{\circ} \mathrm{C}$ overnight, followed by HRP-labelled goat anti-rabbit IgG $(1: 1,000)$ for $1 \mathrm{~h}$ at $37^{\circ} \mathrm{C}$. The protein bands were detected using an ECL kit.

Competitive phage ELISA screening and indirect ELISA for selected clones. ELISA plates (96-well) were coated with $5 \mu \mathrm{g} / \mathrm{ml}$ PCSK9 protein $(100 \mu \mathrm{l} /$ well $)$ at $4^{\circ} \mathrm{C}$ overnight. After incubation with blocking buffer (2\% BSA/PBS) for $1 \mathrm{~h}$, $100 \mu \mathrm{l}$ phage antibody (containing supernatants or purified anti-PCSK9 antibodies) was added to each well, and the plates were incubated at $37^{\circ} \mathrm{C}$ for $1 \mathrm{~h}$. The plates were then washed three times with PBST and incubated with a 1:5,000 dilution of HRP-labelled mouse anti-M13 monoclonal antibody (cat. no. ab50370; Abcam) or HRP-IgG at $37^{\circ} \mathrm{C}$ for $1 \mathrm{~h}$. Then, $100 \mu \mathrm{l} /$ well tetramethylbenzidine peroxidase (TMB) substrate solution was added to initiate the colour reaction, which was then terminated using $2 \mathrm{M}$ sulfuric acid (100 $\mu \mathrm{l} /$ well). The absorbance at $450 \mathrm{~nm}$ was measured using a Elx800 microplate reader (BioTeK Instruments, Inc.), with $2 \%$ BSA as the negative control and PBS as the blank control. All experiments were repeated three times.

PCSK9 inhibition in Hep-G2 cells using purified anti-PCSK9 antibody. Hep-G2 cells $\left(5 \times 10^{5}\right.$ cells $\left./ \mathrm{ml}\right)$ were cultured in a 6-well plate overnight at $37^{\circ} \mathrm{C}$, to generate single-cell monolayers. The supernatant was discarded and replaced with DMEM containing $10 \%$ lipoprotein-deficient serum. After, $24 \mathrm{~h}$, the cells were treated with 1,5 or $10 \mu \mathrm{g} / \mathrm{ml}$ purified antibody or a combination of 0.5 or $1 \mu \mathrm{g} / \mathrm{ml}$ mevinolin, and incubated for $24 \mathrm{~h}$ sequentially. After collection, the LDLR levels of theHep-G2 cells were determined by western blotting.

Inhibitory effect of the anti-PCSK9 antibody on PCSK9-LDLR binding. A microtiter plate was coated with $5 \mu \mathrm{g} / \mathrm{ml}$ rLDLR (recombinant human LDLR; Shanghai Xinfan Biological Technology Co., Ltd.). The biotinylated PCSK9 protein was then mixed with different concentrations of anti-PCSK9 antibody, which were then added to the plate. Bound biotinylated PCSK9 was detected using avidin-HRP and TMB. The reactions were terminated using $50 \mu 1 \mathrm{H}_{2} \mathrm{SO}_{4}(2 \mathrm{M})$ and absorbance was measured at $450 \mathrm{~nm}$.

Measurement for serum cholesterol liver LDLR in mice. All animal experiments were approved by the Ethics Committee of Jilin Medical University. Male C57BL/6J mice (weight, $18-22 \mathrm{~g}$ ) were purchased from the experimental animal centre of Jilin University (Changchun, China), and housed with food and water ad libitum under a constant temperature $\left(23 \pm 1^{\circ} \mathrm{C}\right)$ with a 12-h light/dark cycle. The mice were randomly divided into three groups and intravenously (i.v.) administered purified anti-PCSK9 antibody $(\mathrm{n}=84)$, anti-keyhole limpet hemocyanin antibody (negative control, $\mathrm{n}=21$ ) or PBS (blank control, $\mathrm{n}=21$ ).

A total of 21 mice were randomly selected from each group and received a single i.v. injection of anti-PCSK9 antibody $(10 \mathrm{mg} / \mathrm{kg})$. The serum was collected at different time points post-injection (24, 48 and $72 \mathrm{~h} ; 7$ mice/group). The remaining 63 mice in the anti-PCSK9 antibody group were injected with different concentrations of anti-PCSK9 antibody, and the serum was collected at 3,6 and 9 days after injection. The total cholesterol (TC) levels were determined using a TC detection kit (cat. no. A111-1-1; Nanjing Jiancheng Bioengineering Institute).

The mice were sacrificed by cervical dislocation, and protein was extracted from the livers $(24,48$ and $72 \mathrm{~h}$ post-injection groups) using a Membrane and Cytosol Protein Extraction Kit (cat. no. G4422-2; GBCBIO Technologies Inc.). Western blotting was conducted using LDLR and GAPDH antibodies (both Abcam) to determine the levels of LDLR following PCSK9 treatment.

Statistical analysis. Statistical analyses were conducted using Originpro version 9.1 (OriginLab). All of the results conformed to a normal distribution and are expressed as the mean \pm SEM. The t-test was used to compare two groups. $\mathrm{P}<0.05$ was considered to indicate a statistically significant difference. 
A

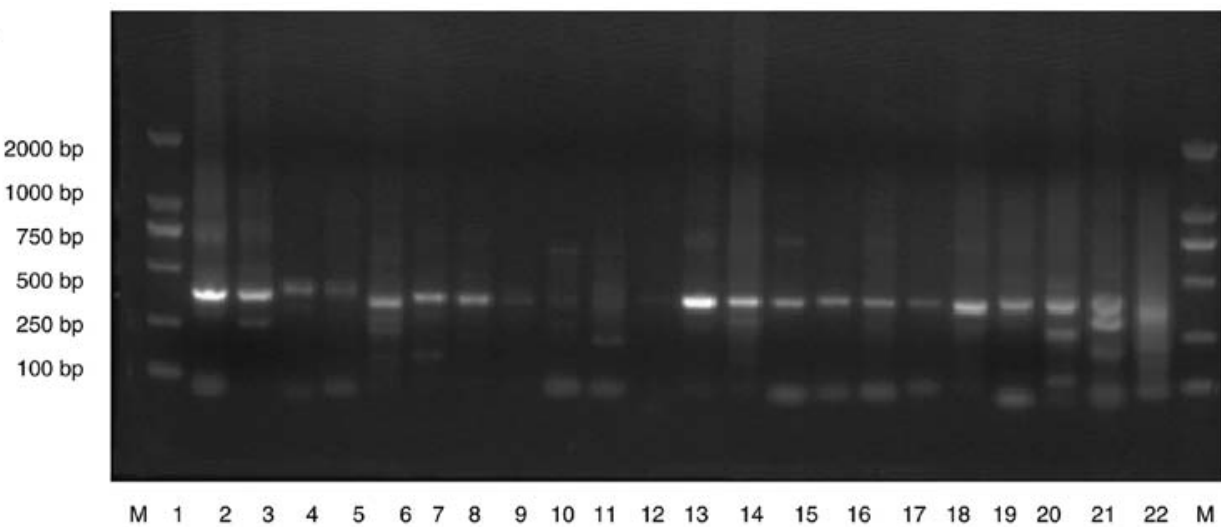

B

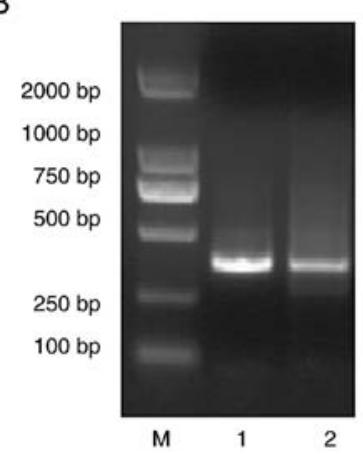

C

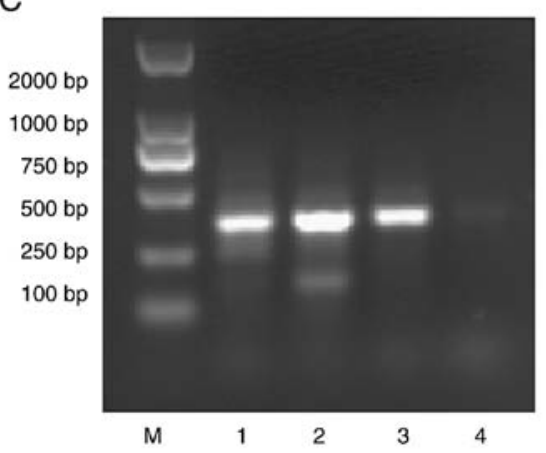

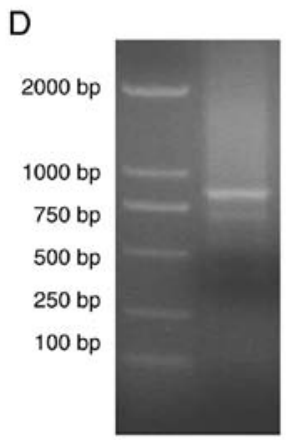

M

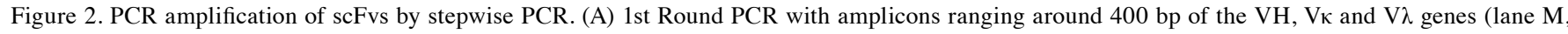
DNA marker 2000; lane 1-11, Vк; lane 12-18, V $\lambda$; lane 19-22, VH). (B-D) 1st Round products were gel-purified and used as the templates for 2nd round PCR. 2nd Round PCR with amplicons ranging around $400 \mathrm{bp}$ of the Vk-linker, V $\lambda$-linker (B, lane M, DNA marker 2000; lane 1, Vk-linker; lane 2, V $\lambda$-linker) and VH-linker (C, lane M, DNA marker 2000; lane 1-4, VH-linker) fragments were also gel-purified and used as the templates for overlap PCR of the scFvs (D, Lane M, DNA marker 2000; lane 1, scFv). Amplicons ranging around $800 \mathrm{bp}$ were recovered and stored at $-80^{\circ} \mathrm{C}$. scFv, single-chain fragment variable; $\mathrm{VH}$, heavy chain variable region; VL, light chain variable region.

\section{Results}

Construction of fully human scFv phage display library. Stepwise PCR was used to synthesize fully human scFvs for library construction (Fig. 1). The concentration of total RNA was $2,164 \mathrm{ng} / \mu \mathrm{l}$ with a A260/A280 ratio of 1.935 (data not shown). Following amplification of the $\mathrm{VH}, \mathrm{V \kappa}$ and $\mathrm{V} \lambda$ genes (Fig. 2A-C), amplicons ranging around $400 \mathrm{bp}$ were obtained and used as the templates for overlap PCR. Ultimately, the amplicons ranging around $800 \mathrm{bp}$ of the scFv (Fig. 2D) were recovered and cloned into $\mathrm{pDF}$ vectors. After recombination of the library in the BS1365 strain, the library size was estimated to be $\sim 1 \times 10^{11}$ cells $/ \mathrm{ml}$ (Fig. 3A). Tests for library accuracy and diversity, based on 60 colony PCR and $s c F v$ gene sequencing results, are shown in Fig. 3B, which confirm $>75 \%$ sequence variation. Sequence blast results revealed that VL and $\mathrm{VH}$ were consistent with the human antibody sequences (data not shown).

Generation of human PCSK9 recombinant protein. The human PCSK 9 gene is transcribed into a 3,637 bp linear mRNA, and is primarily expressed in the liver. Thus, PCSK9 was amplified from hepatic Hep-G2 cells using reverse transcription PCR (15). The recombinant vector, pcDNA3.1-hIgG1FC-PCSK9, was successfully constructed and expressed in Chinese hamster ovary (CHO)-K1 cells. After purification, human PCSK9 in the cell supernatant was analysed by SDS-PAGE (Fig. 4A).
Ultimately, two distinct bands were observed at 70 and $17 \mathrm{kDa}$, which correspond to the catalytic C-terminal domains and the prodomain, respectively (16).

Selection of human scFv antibodies against PCSK9 using a phage display library. The human scFv phage library was based on Cre-LoxP511 system in vivo recombination for $\mathrm{VH}$ and $\mathrm{VL}$ generation, and was constructed using a pDF vector (Fig. 4B). The library comprised $1 \times 10^{11}$ clones, which were screened against recombinant PCSK9 protein. A total of 4 rounds of selection were performed on immobilized PCSK9, detected by phage ELISA. As shown in Fig. 4C, a significant enrichment of $80 \%$ was reached after the fourth selection. Ultimately, 24 colonies recovered from the fourth round showed high binding affinity for PCSK9 (Fig. 4D). All clones exhibited the characteristics of the human antibody gene (Table II). A total of five different $\mathrm{scFv}$ sequences were identified; the light chains of 2C7 and 3D2 were $\kappa$ type, while 3B9, 7E4 and 12D6 were $\lambda$ type. For comparison, an NCBI online constraint-based multiple alignment tool showed that there were differences in CDR region among the five clones, in which both the VL $\kappa$ types of CDR3 and the VL-CDRs of $\lambda$ type, as well as the CDRs of variable heavy chain regions, were significantly different between the five clones.

Construction and characterization of fully human PCSK9 fragments. To generate fully human scFv antibodies, the 
Table II. Five sequences of scFvs obtained after four rounds of screening, among which the complementarity-determining regions (CDRs) were significantly different.

Five sequences of scFvs

\begin{tabular}{|c|c|}
\hline & CDR2 \\
\hline 12D6 & DIVMTQTPS-VSVAPGKTARITCGGKDIGSKSVHWYQQKPGQAPVLVIYYDSDRPSGIPE \\
\hline 3B9 & DIVLTQSPS-VSVAPGKTARITCGGNDIGSKSVHWYQQKPGQAPVLVIYYDSDRPSGIPE \\
\hline 7F4 & DIVLTQAPS-VSVAPGKTARITCEPQEIGSKSVHWYQQKPGQAPVLVIYYDSDRPSGIPE \\
\hline 3D2 & EIVLTQSPVTLSVSPGERATLSCRASQSVIGNLAWYQQKPGQAPRLLIYGASARAAGIPD \\
\hline $2 \mathrm{C} 7$ & $\begin{array}{c}\text { EIVLTQSPATLSVSPGERATLSCRASQSVLVNLAWYQQKPGQAPRLLIYGASRVESGIPD } \\
\text { CDR3 }\end{array}$ \\
\hline 12D6 & RFSGSNSGNTATLTISRVEAGDEADYYCAAAWDDSLNGPVFGGGTKVEIKRSGGSTITSNN \\
\hline 3B9 & RFSGSNSGNTATLTISRVEAGDEADYYCHDWDESORRPVFGGGTKGEIKRSGGSTITSNN \\
\hline 7F4 & RFSGSNSGNTATLTISRVEAGDEADYYCAEQDRRLHSQVFGGGTKVEIKRSGGSTITSNN \\
\hline $3 \mathrm{D} 2$ & RFSGSGSGTDFTLTISSLKSEDFAVYYCQQYGSS-PYTFGQGTKLEIKRSGGSTITSNN \\
\hline $2 \mathrm{C} 7$ & $\begin{array}{c}\text { RFSGSGSGTEFTLTISSLKSEDFAVYYCQQYTLA-SGTFGQGTKLEIKRSGGSTITSNN } \\
\text { CDR1 }\end{array}$ \\
\hline 12D6 & VYLRKLSSSGTQVQLVQSGAEVKKPGASVKVSCKVSGYSFDTLGIHWVRRAPGKGLEWMG \\
\hline 3B9 & VYLRKLSSSGTQVQLVQSGAEVKKPGASVKVSCKSSGYGLEALGIQWVRWAPGTGLEWMG \\
\hline 7F4 & VYLRKLSSSGTQVQLVQSGAEVKKPGASVKVSCQASGVTDHGYDIHWVRQATGQGLEWMG \\
\hline 3D2 & VYLRKLSSSGTQVQLVQSGAEVKKPGSSVKVSCQASGGTFSGYDIHWVRQATGQGLEWMG \\
\hline $2 \mathrm{C} 7$ & $\begin{array}{l}\text { VYLRKLSSSGTQVQLVQSGAEVKKPGASVKVSSKVS } \overline{\text { ASRCVTLSIHWVRLAPGKGLEWMG }} \\
\text { CDR2 } \\
\text { CDR3 }\end{array}$ \\
\hline 12D6 & WISPYNGNTDYAQNLQDRVSMTTDTSTSTAYMELRSLRSDDTAVYYCARVYSYSMDYWGQ \\
\hline 3B9 & WISAYNGNTDYAQHFEDRVSMTTDTSTSTAYLELRSLRSDDTAVYYCVHGYSYRVGYWGQ \\
\hline $7 \mathrm{~F} 4$ & WMNPLVGADRYAQKFQGRVTMTRDTSTATAYMELTSLTSDDTAVYYCAR-YAHTSLEWGQ \\
\hline $3 \mathrm{D} 2$ & WMNPHSGNAGYAQKFQGRVTMTRDTSTATAYMELTSLTSDDTAVYYCAR-YAQLSLEWGQ \\
\hline $2 \mathrm{C} 7$ & WISRSTDSRVYAQNLHVTVFMTTDTSTSTAYMELRSLRSDDTAVYYC \\
\hline 12D6 & GTLVTVSS \\
\hline 3B9 & GTLVTVSS \\
\hline $7 \mathrm{~F} 4$ & GTLVTVSS \\
\hline $3 \mathrm{D} 2$ & GTLVTVSS \\
\hline $2 \mathrm{C} 7$ & GTLVTVSS \\
\hline
\end{tabular}

The letters in bold and underline were the CDRs of the five scFvs.

$\mathrm{VH}$ and VL regions of the five selected $\mathrm{scFv}$ clones were separately subcloned into pcDNA3.1-CL and pcDNA3.1-CH expression vectors (Fig. 5A). Antibodies were expressed in 293 cells and purified using protein A affinity chromatography. The yields of the five antibodies ranged between 50 and $200 \mathrm{mg} / \mathrm{l}$ per culture. SDS-PAGE analysis of the 3D2 antibody revealed that it consisted of a $25 \mathrm{kDa} \mathrm{VL}$ and a 50 $\mathrm{kDa} \mathrm{VH}$ region under reducing conditions, and formed a 170 kDa homodimer under non-reducing conditions, which are typical patterns of human $\operatorname{IgG}$ (Fig. 5B). Western blotting and indirect ELISA were used to assess the specificity of the five selected antibodies against PCSK9. The data indicated that all of the antibodies specifically bound the PCSK9 protein in a dose-dependent manner (Fig. 5C). Moreover, antibody affinity was determined using BLI technology, revealing $\mathrm{K}_{\mathrm{D}}$ values ranging from $8.77 \times 10^{-9}$ to $3.28 \times 10^{-10} \mathrm{M}$ (Fig. $5 \mathrm{D}$ and $\mathrm{T}$ able III). These data suggest that the five fully human scFv fragments were specific for PCSK9.
Human 3D2 antibody inhibits PCSK9 function in vitro. Functional properties of the five PCSK9 antibodies were characterized using in vitro assays. Of these five antibodies, only 3D2 was able to bind PCSK9, thereby blocking the PCSK9-LDLR interaction with an $\mathrm{IC}_{50}$ of $2.25 \pm 1.23 \mathrm{nM}$ $(\mathrm{n}=3)$ (Fig. 6A). After 24-48 h of incubation with 1,3 or $10 \mu \mathrm{g} / \mathrm{ml} 3 \mathrm{D} 2$, the LDLR levels in the Hep-G2 cells increased 1.3-2.5 fold compared with those in the untreated cells (Fig. 6B). In addition, previous reports have indicated that statins induce the expression of both LDLR and PCSK9 (17); therefore, in the present study, the effects of combining 3D2 antibody and statin administration on Hep-G2 cell LDLR levels were investigated. Hep-G2 cells were treated with the statin mevinolin and/or 3D2, and the levels of LDLR protein in cell lysates were determined using western blotting (Fig. 6C). The results indicate that combined administration was more effective than that of mevinolin or 3D2 alone; $1 \mu \mathrm{g} / \mathrm{ml}$ mevinolin combined with 

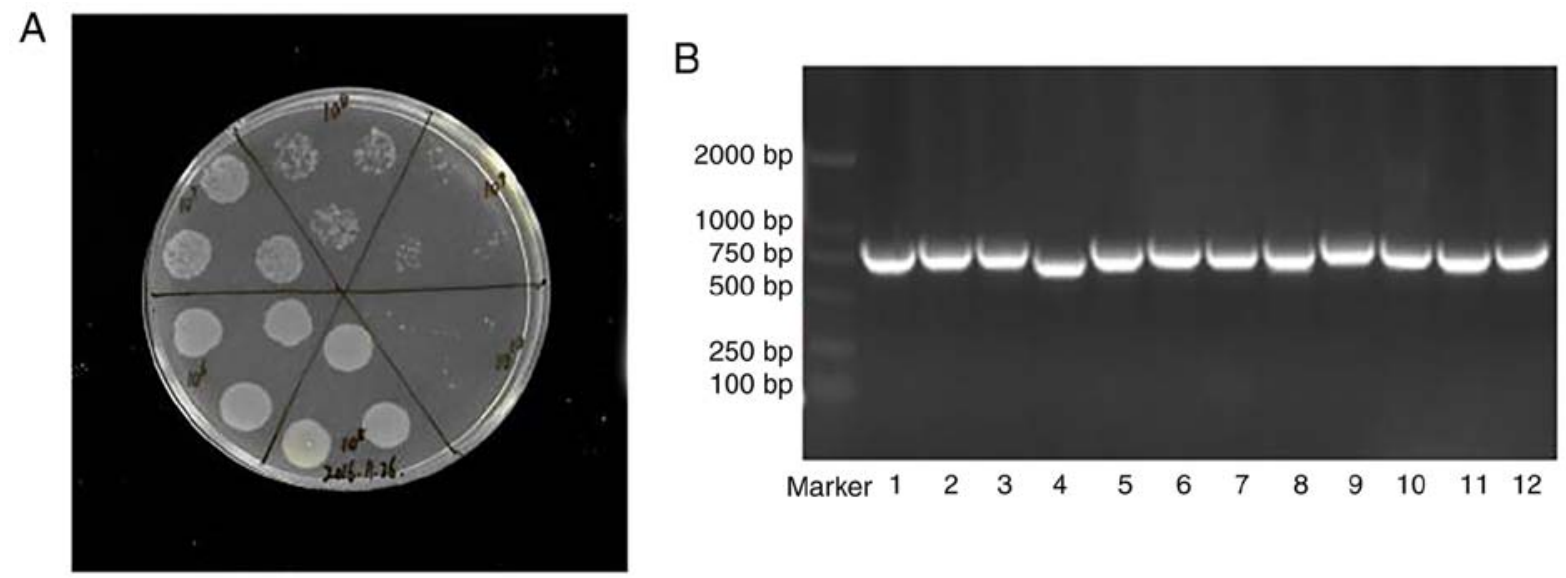

Figure 3. (A) After recombination of the library in E. coli strain BS1365, the library size was investigated by inoculating culture plates with $10 \mu 1$ BS1365 in triplicate, and counting the number of colonies; the library was estimated to be $1 \times 10^{11}$ cells $/ \mathrm{ml}$. (B) Determination of the accuracy and diversity of the library based on PCR of 60 colonies PCR (Fig. 3B) confirmed that $>75 \%$ of the sequences were different from each other.
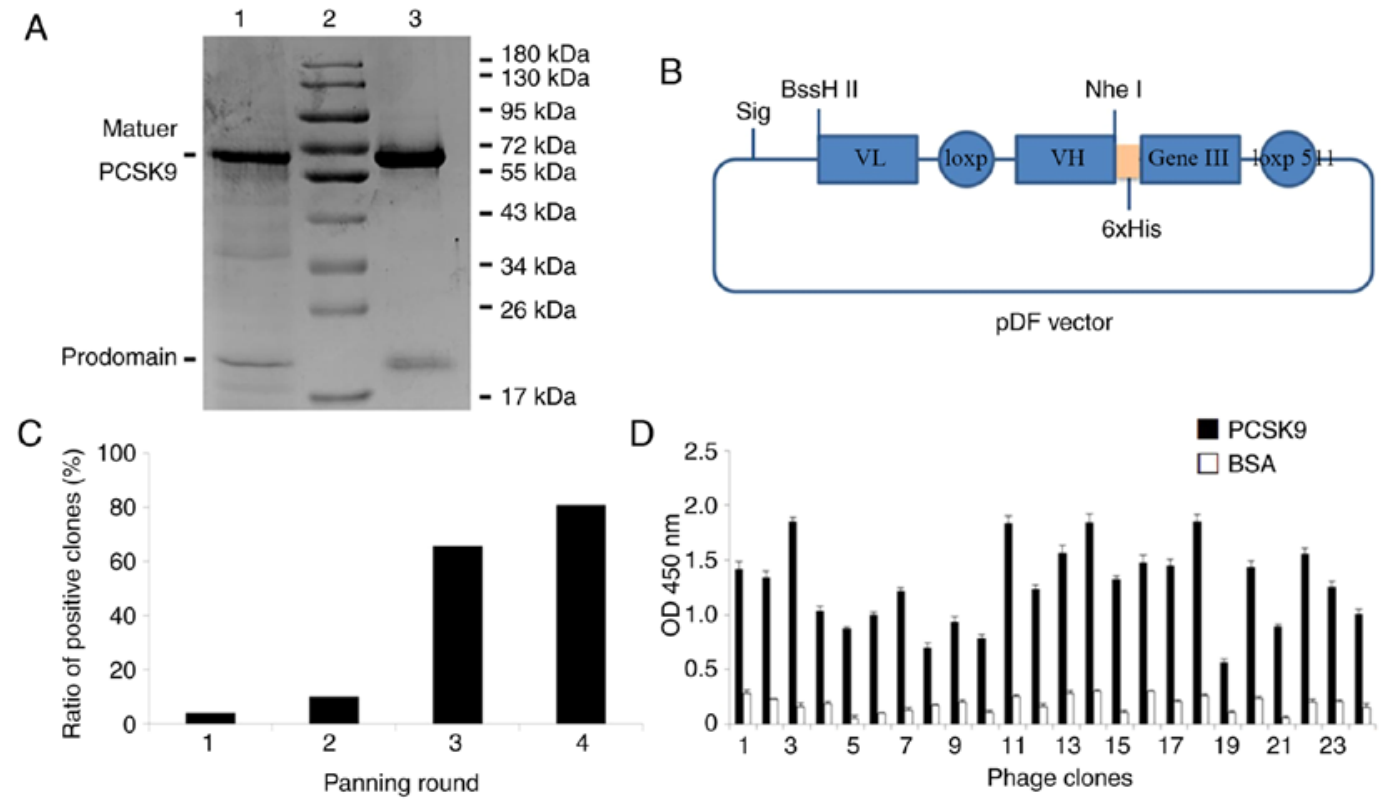

Figure 4. Phage screening of anti-PCSK9 antibodies. (A) After purification, human PCSK9 protein in the cell culture supernatant was separated by SDS-PAGE under reducing conditions. Lane 1 and 3, purified PCSK9 protein; lane 2, protein molecular weight marker. (B) Phagemid vector pDF was used for the construction of the scFv display library. (C) Ratio of positive clones during the four rounds of selection. (D) Identification of the binding selectivity of 24 clones detected by phage ELISA. PCSK9, proprotein convertase subtilisin/kexin 9; scFv, single-chain fragment variable.

$10 \mu \mathrm{g} / \mathrm{ml} 3 \mathrm{D} 2$ increased the levels of LDLR protein up to 9.0 fold compared with untreated cells. These data suggest that the 3D2 antibody is a potential auxiliary treatment for decreasing cellular lipid levels.

Human 3D2 antibody reduces serum cholesterol by increasing hepatic LDLR in mice. Experiments were performed to verify whether human 3D2 antibody could also increase hepatic LDLR levels in vivo, and subsequently reduce serum TC. C57BL/6J mice ( $n=7$ per group) were treated with a single i.v. injection of 3D2 $(10 \mathrm{mg} / \mathrm{kg})$. The results indicate that 3D2 significantly reduced serum TC levels at 24,48 and $72 \mathrm{~h}$ post-injection by $33.5 \pm 0.54 \%(\mathrm{P}<0.05), 53.9 \pm 0.85 \%(\mathrm{P}<0.05)$, and $61.5 \pm 1.2 \%$ $(\mathrm{P}<0.01)$, respectively (Fig. 6D). However, the phenomenon was reversible, and the effect was duration-dependent (Fig. 6F). By day 9 , the TC levels in all treatment groups were not signifi- cantly different from those in the control group. Furthermore, hepatic LDLR protein levels were increased 2.0-fold (Fig. 6E), which indicates that the increase in LDLR level was positively associated with a decrease in the lipid profile, and that the 3D2 antibody reduces lipid levels in vivo.

\section{Discussion}

The fully human scFv phage display library holds great value for the development of antibody-based treatments. The construction of a human scFv library is theoretically simple, but a high-quality library is difficult to obtain. There are three main indexes used to evaluate the quality of a phage display library, including gene diversity, library size and screening ability. In the present study, these three key indexes were used to optimize the construction of the human scFv library. 
Table III. Binding affinities of antibodies with recombinant PCSK9 protein. ${ }^{\mathrm{a}}$

\begin{tabular}{lccr}
\hline Antibody & $\mathrm{K}_{\text {on }}\left(10^{6} \mathrm{M}^{-1} \mathrm{~S}^{-1}\right)$ & $\mathrm{K}_{\text {off }}\left(10^{-4} \mathrm{~S}^{-1}\right)$ & $\mathrm{K}_{\mathrm{D}}\left(10^{-9} \mathrm{M}\right)$ \\
\hline 2C7 & $3.16 \pm 1.11$ & $6.74 \pm 2.26$ & $21.4 \pm 7.21$ \\
3B9 & $2.49 \pm 1.21$ & $8.15 \pm 3.22$ & $32.8 \pm 13.1$ \\
3D2 & $2.59 \pm 1.58$ & $5.08 \pm 4.02$ & $19.6 \pm 15.6$ \\
$7 \mathrm{~F} 4$ & $5.27 \pm 1.60$ & $4.62 \pm 2.18$ & $8.77 \pm 4.92$ \\
$12 \mathrm{D} 6$ & $2.94 \pm 2.41$ & $8.36 \pm 3.70$ & $28.5 \pm 12.8$
\end{tabular}

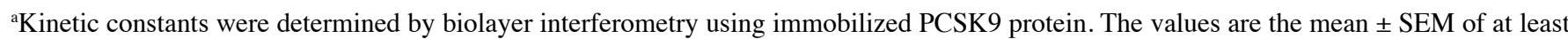
three independent experiments.

A

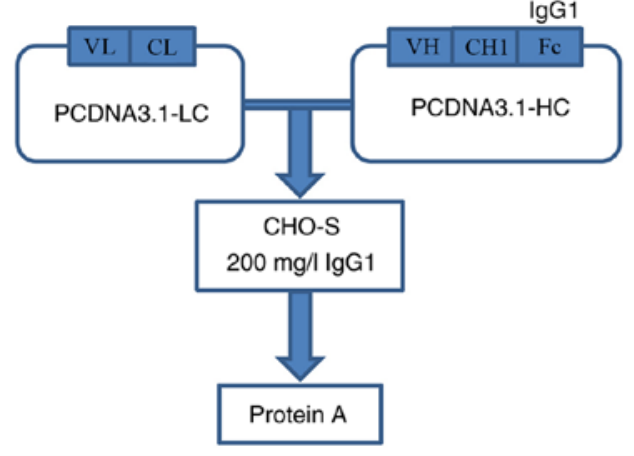

C

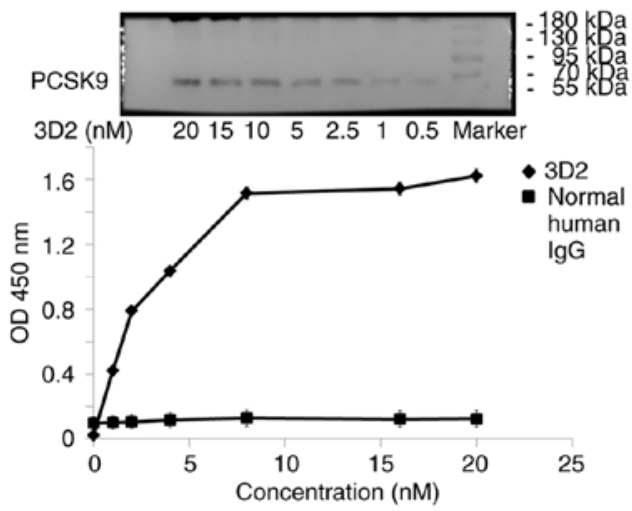

B
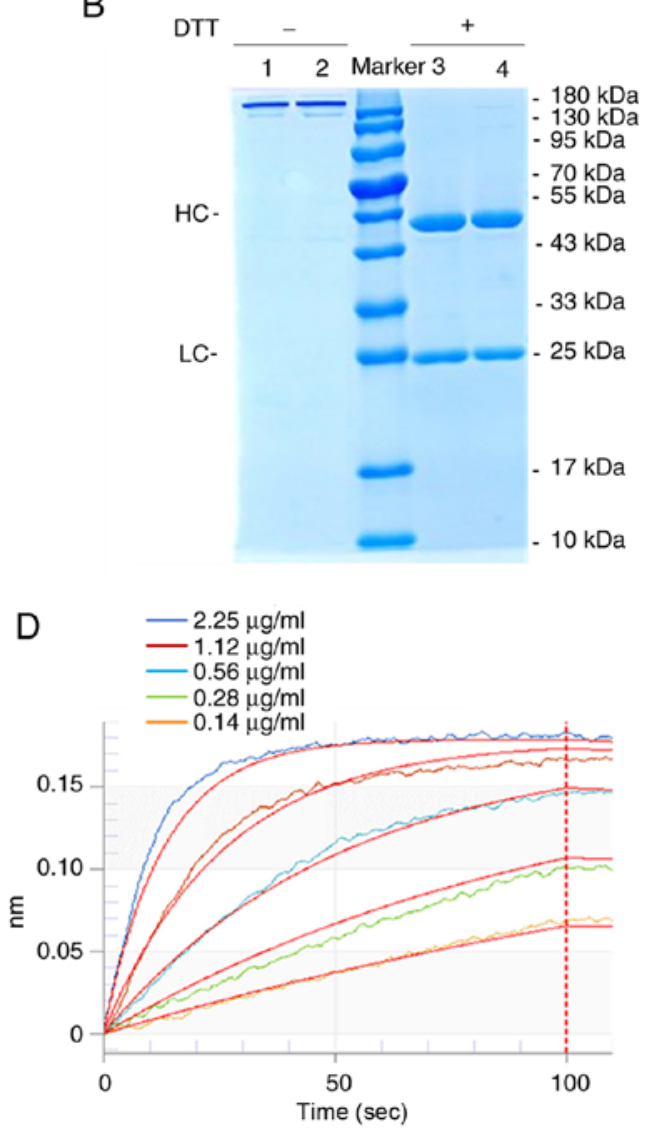

Figure 5. Generation and characterization of fully anti-PCSK9 antibodies. (A) Flow diagram for the construction of expression plasmids. (B) Reducing and non-reducing SDS-PAGE detection of 3D2 fully anti-PCSK9 antibody (lane 1, non-reducing conditions; lane 3, reducing conditions) and normal human IgG control antibody (lane 2, non-reducing conditions; lane 4, reducing conditions). (C) Western blotting and indirect binding ELISA were performed to assess the specificity of 3D2 against PCSK9. (D) Affinity of 3D2 was determined by biolayer interferometry technology. PCSK9, proprotein convertase subtilisin/kexin 9.

A total of 400 blood, 30 bone marrow and 10 cord blood samples were collected from healthy donors. Donors were recruited via different sources to avoid the bias of individual antibody genes, and to ensure the diversity of the $s c F v$ gene. The $s c F v$ gene was amplified in strict accordance with the proportion of antibody genes of different human germlines, and imitated the human antibody gene repertoire to the maximal extent. The results of randomly sequencing $60 \mathrm{scFvs}$ revealed that the diversity of the constructed phage display library was consistent with the antibody gene distribution of the human germline.
The simplest way to evaluate the quality of an antibody library is by size. Theoretically, the larger the capacity of the library, the higher the affinity of the screened antibodies. The key factors that affect antibody library size are primarily the efficiencies of gene splicing and electrotransformation. Splicing of antibody light and heavy chain genes is generally conducted by overlap PCR. After a long period of investigation, the optimal protocol and conditions for overlap PCR amplification were determined. A primary human $\mathrm{scFv}$ library ( $5 \times 10^{7}$ in size) was constructed from peripheral and cord blood samples, and a primary human scFv library $\left(5 \times 10^{7}\right.$ in size $)$ was 
A

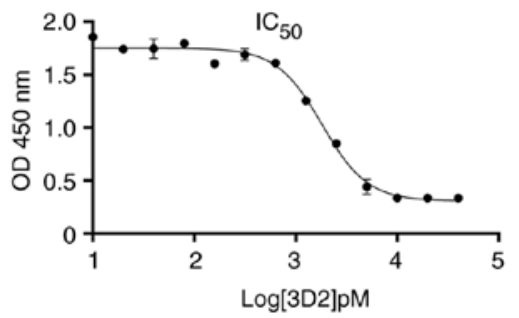

C

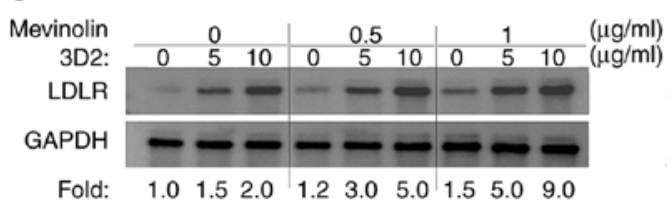

E

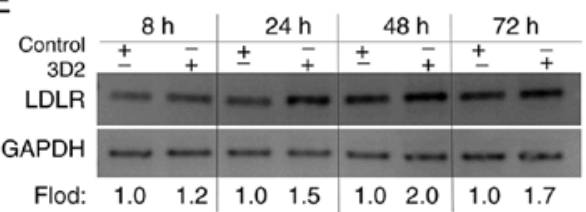

B
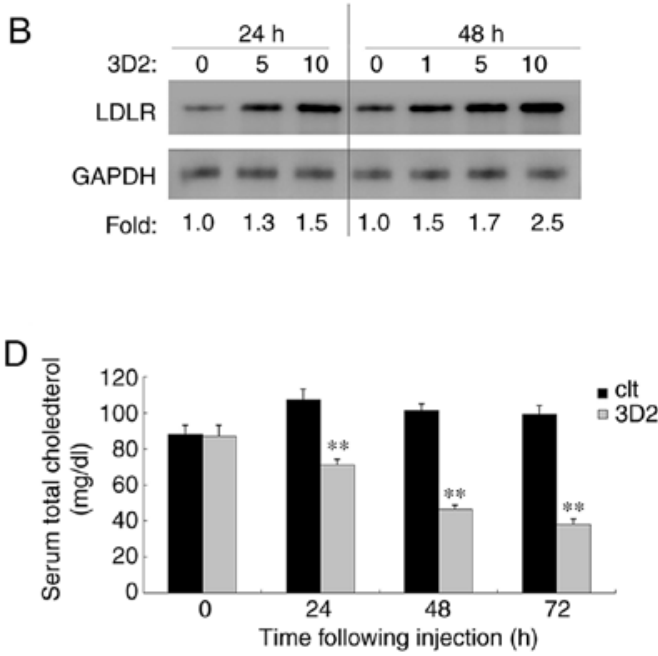

$\mathrm{F}$

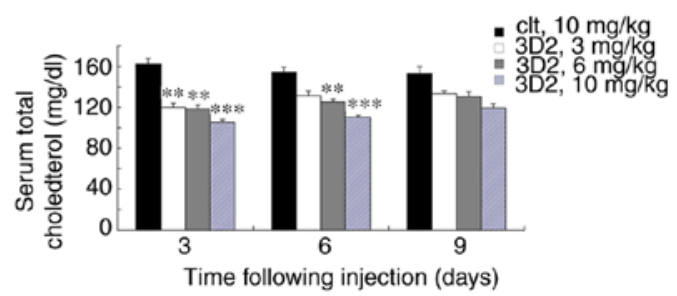

Figure 6. Human 3D2 antibody inhibits PCSK9 function. (A) 3D2 inhibits the binding of PCSK9 to LDLR in a dose-dependent manner, with an IC ${ }_{50}$ of $2.25 \pm 1.23 \mathrm{nM}$. (B) Western blotting indicated that after $24-48 \mathrm{~h}$ of incubation with 1,3 or $10 \mu \mathrm{g} / \mathrm{ml} 3 \mathrm{D} 2$, Hep-G2 cell LDLR levels were increased $1.3-$ to 2.5 -fold, compared with those in untreated cells. GAPDH served as the loading control. (C) Hep-G2 cells were treated with mevinolin (0.5 or $10 \mathrm{~g} / \mathrm{ml})$ and/or $3 \mathrm{D} 2(5$ or $10 \mu \mathrm{g} / \mathrm{ml})$ for $48 \mathrm{~h}$, and the levels of LDLR protein in the cell lysates were assessed by western blotting. (D) C57BL/6J mice (n=7 per group) were administered a single i.v. injection of 3D2 antibody $(10 \mathrm{mg} / \mathrm{kg})$ and serum TC levels were determined at 24,48 and $72 \mathrm{~h}$. (E) Hepatic LDLR protein levels at 8 , 24,48 and $72 \mathrm{~h}$ post-injection were analysed by western blotting; the fold change was calculated as the ratio of LDLR in the presence or absence of $3 \mathrm{D} 2$ antibody for each time point after normalization of the LDLR to GAPDH in each lane. GAPDH served as the loading control. (F) Mice ( $\mathrm{n}=7$ per group) were injected with a single dose of 3,6 or $10 \mathrm{mg} / \mathrm{kg}$ 3D2 antibody, and serum TC levels were determined at 3,6 and 9 days, respectively. Results are expressed as the mean \pm SEM. ${ }^{* *} \mathrm{P}<0.05$ and $^{* * * *} \mathrm{P}<0.01$ vs. control. PCSK9, proprotein convertase subtilisin/kexin 9; LDLR, low-density lipoprotein receptor; TC, total cholesterol.

constructed using bone marrow samples. By optimizing the recombinant conditions, the primary library was used to infect the BS1365 E. coli strain, which expresses the Cre enzyme. Using Cre-LoxP enzyme-mediated heavy and light chain replacement recombination, a recombinant human $\mathrm{ScFv}$ phage display library with a library size of $1 \times 10^{11}$ was obtained. The most important parameter for antibody library quality is the ability to screen antibodies. The scFv library constructed in the present study can be used to screen antibodies with an affinity of $3.28 \times 10^{-10} \mathrm{M}$ through the screening and verification of those specific to PCSK9, which confirms the optimal quality of the scFv phage display library.

Various studies have indicated that anti-PCSK9 antibodies are powerful inhibitors of PCSK9 $(18,19)$, thus the generation of a novel and less immunogenic human antibody with greater in vivo efficacy is of great clinical significance. In the current study, recombinant human PCSK9 protein was used to screen human $\mathrm{scFv}$ antibodies. After 4 rounds of selection, an $\mathrm{scFv}$ antibody with high affinity for PCSK9, 3D2, was obtained. Further experimentation revealed that 3D2 increased hepatic LDLR levels in vivo and vitro, which in turn reduced serum TC.

Due to low circulating LDL-C levels in their blood, wild-type C57BL/6J mice are generally not suitable for the study of cholesterol-lowering drugs (20). However, some in vivo studies of PCSK9-targeted compounds revealed enhanced levels of PCSK9 in the serum of mice. Rashid et al (21) found that TC levels were elevated in the serum, and the LDLR levels in hepatocytes were reduced in mice receiving an i.v. injection of PCSK9. To investigate its neutralizing activity, Schroeder et al (22) treated mice with an i.v. injection of an adeno-associated virus (AAV) vector carrying the PCSK9 gene, followed by injection of the candidate antibody. Furthermore, Barale et al (23) obtained a human anti-PCSK9 antibody (mAb1) using the hybridoma technique, which had cross-reactivity with murine PCSK9 and significantly decreased serum cholesterol in WT C57BL/6J mice. In the present study, the 3D2 human anti-PCSK9 antibody, which also cross-reacted with murine PCSK9 (data not shown), effectively reduced serum cholesterol by increasing hepatic LDLR in mice.

In summary, the present study outlines the construction of a human scFv phage antibody library, with large library size and diversity, using Cre-LoxP in vitro recombination. By screening with recombinant human PCSK9 antigen, the diversity and screening ability of the constructed antibody library was further confirmed, and it can be used for screening other target antibodies. The fully human anti-PCSK9 antibody, 3D2, was found to neutralize PCSK9 activity in vitro and in vivo, demonstrating its potential for future clinical development.

\section{Acknowledgements}

Not applicable. 


\section{Funding}

This study was supported by the following financial programs: 'Research and Development of Industrial Technology' Program of Jilin Province, PR China (grant nos. 20170204005YY and 20180623045TC), Program of Jilin Science and Technology bureau, P.R. China (grant nos. 2019001179 and 20200104093), Health Commission Program of Jilin Province (no. 2020Q029) and National Training Program of Innovation and Entrepreneurship for Undergraduates (nos. 201913706005, 201913706039 and 202013706008).

\section{Availability of data and materials}

The datasets used and/or analyzed during the current study are available from the corresponding author on reasonable request.

\section{Ethics approval and consent to participate}

The present study was approved by the ethics committee of Jilin Medical University (approval no. 2016-LW012) prior to the start of the study. Informed consents for the collection of peripheral blood, bone marrow and cord were obtained from all subjects.

\section{Authors' contributions}

YD and FM constructed the scFv phage display library. ZW and SX prepared the antigen. TY was responsible for cell culture. AC and JW screened the antibody. MY analyzed the data regarding the characterization of antibody. LT and $\mathrm{CH}$ purified the protein. HW determined the hypolipidemic effects of antibody. JC analyzed all the data and wrote the manuscript. All authors read and approved the final manuscript.

\section{Patient consent for publication}

Written informed consent for publication was obtained from all participants.

\section{Competing interests}

The authors declare that they have no competing interests.

\section{References}

1. Zhang Y, Wang W, Lv M, Lin Z, Geng J, Li Y, Shen B, Ma Y, Li Y, Qiao C and Feng J: A single-chain antibody using LoxP511 as the linker enables large-content phage library construction via Cre/LoxP recombination. J Biomol Screen 19: 839-846, 2014.

2. Zhang GM, Chen YP, Guan YZ, Wang Y and An YQ: Modification and identification of a vector for making a large phage antibody library. Chin Med J (Engl) 120: 2011-2016, 2007.

3. Baragetti A, Grejtakova D, Casula M, Olmastroni E, Jotti GS, Norata GD, Catapano AL and Bellosta S: Proprotein convertase subtilisin-Kexin type-9 (PCSK9) and triglyceride-rich lipoprotein metabolism: Facts and gaps. Pharmacol Res 130: 1-11, 2018.

4. Abifadel M, Varret M, Rabès JP, Allard D, Ouguerram K, Devillers M, Cruaud C, Benjannet S, Wickham L, Erlich D, et al: Mutations in PCSK9 cause autosomal dominant hypercholesterolemia. Nat Genet 34: 154-156, 2003.

5. Cohen J, Pertsemlidis A, Kotowski IK, Graham R, Garcia CK and Hobbs HH: Low LDL cholesterol in individuals of African descent resulting from frequent nonsense mutations in PCSK9. Nat Genet 37: 161-165, 2005.
6. Huang CC, Fornage M, Lloyd-Jones DM, Wei GS, Boerwinkle E and Liu K: Longitudinal association of PCSK9 sequence variations with low-density lipoprotein cholesterol levels: The Coronary Artery Risk Development in Young Adults Study. Circ Cardiovasc Genet 2: 354-361, 2009.

7. Frank-Kamenetsky M, Grefhorst A, Anderson NN, Racie TS, Bramlage B, Akinc A, Butler D, Charisse K, Dorkin R, Fan Y, et al: Therapeutic RNAi targeting PCSK9 acutely lowers plasma cholesterol in rodents and LDL cholesterol in nonhuman primates. Proc Natl Acad Sci USA 105: 11915-11920, 2008.

8. Ray KK, Stoekenbroek RM, Kallend D, Leiter LA, Landmesser U, Wright RS, Wijngaard P and Kastelein JJP: Effect of an siRNA therapeutic targeting PCSK9 on atherogenic lipoproteins: Prespecified secondary end points in ORION 1. Circulation 138: 1304-1316, 2018.

9. Duff CJ, Scott MJ, Kirby IT, Hutchinson SE, Martin SL and Hooper NM: Antibody-mediated disruption of the interaction between PCSK9 and the low-density lipoprotein receptor. Biochem J 419: 577-584, 2009.

10. Dubuc G, Chamberland A, Wassef H, Davignon J, Seidah NG, Bernier L and Prat A: Statins upregulate PCSK9, the gene encoding the proprotein convertase neural apoptosis-regulated convertase-1 implicated in familial hypercholesterolemia. Arterioscler Thromb Vasc Biol 24: 1454-1459, 2004.

11. Careskey HE, Davis RA, Alborn WE, Troutt JS, Cao G and Konrad RJ: Atorvastatin increases human serum levels of proprotein convertase subtilisin/kexin type 9. J Lipid Res 49: 394-398, 2008

12. Tonikian R, Zhang Y, Boone $\mathrm{C}$ and Sidhu SS: Identifying specificity profiles for peptide recognition modules from phage-displayed peptide libraries. Nat Protoc 2: 1368-1386, 2007.

13. Lakzaei M, Rasaee MJ, Fazaeli AA and Aminian M: A comparison of three strategies for biopanning of phage-scFv library against diphtheria toxin. J Cell Physiol 234: 9486-9494, 2019.

14. Tohidkia MR, Sepehri M, Khajeh S, Barar J and Omidi Y: Improved soluble ScFv ELISA screening approach for antibody discovery using phage display technology. SLAS Discov 22: 1026-1034, 2017

15. Grozdanov PN, Petkov PM, Karagyozov LK and Dabeva MD: Expression and localization of PCSK9 in rat hepatic cells. Biochem Cell Biol 84: 80-92, 2006.

16. Lipari MT, Li W, Moran P, Kong-Beltran M, Sai T, Lai J, Lin SJ, Kolumam G, Zavala-Solorio J, Izrael-Tomasevic A, et al: Furin-cleaved proprotein convertase subtilisin/kexin type 9 (PCSK9) is active and modulates low density lipoprotein receptor and serum cholesterol levels. J Biol Chem 287: 43482-43491, 2012.

17. Rodriguez F and Harrington RA: Cholesterol, cardiovascular risk, statins, PCSK9 inhibitors, and the future of LDL-C lowering. JAMA 316: 1967-1968, 2016.

18. Harada LM, Carrilho AJ, Oliveira HC, Nakandakare ER and Quintão EC: Regulation of hepatic cholesterol metabolism in CETP/LDLr mice by cholesterol feeding and by drugs (cholestyramine and lovastatin) that lower plasma cholesterol. Clin Exp Pharmacol Physiol 33: 1209-1215, 2006.

19. Cao Y, Yang H, Zhou X, Mao H, Gao T, Hu Z, He L, Pan F and Guo Z: Selection and characterization of human PCSK9 antibody from phage displayed antibody library. Biochem Bioph Res Commun 463:712-718, 2015.

20. Lie J, de Crom R, van Gent T, van Haperen R, Scheek L, Sadeghi-Niaraki F and van Tol A: Elevation of plasma phospholipid transfer protein increases the risk of atherosclerosis despite lower apolipoprotein B-containing lipoproteins. J Lipid Res 45: 805-811, 2004.

21. Rashid S, Curtis DE, Garuti R, Anderson NN, Bashmakov Y, Ho YK, Hammer RE, Moon YA and Horton JD: Decreased plasma cholesterol and hypersensitivity to statins in mice lacking Pcsk9. Proc Natl Acad Sci USA 102: 5374-5379, 2005.

22. Schroeder KM, Beyer TP, Hansen RJ, Han B, Pickard RT, Wroblewski VJ, Kowala MC and Eacho PI: Proteolytic cleavage of antigen extends the durability of an anti-PCSK9 monoclonal antibody. J Lipid Res 56: 2124-2132, 2015.

23. Barale C, Bonomo K, Frascaroli C, Morotti A, Guerrasio A, Cavalot $\mathrm{F}$ and Russo I: Platelet function and activation markers in primary hypercholesterolemia treated with anti-PCSK9 monoclonal antibody: A 12-month follow-up. Nutr Metab Cardiovasc Dis 30: 282-291, 2020. 